\title{
Charcot-Marie-Tooth disease in northern Sweden: pedigree analysis and the presence of the duplication in chromosome $17 \mathrm{p} 11.2$
}

Department of

Neurology, University

Hospital, Umeå,

Sweden

B H Holmberg

Clinical Genetics, University Hospital,

Umeå, Sweden

G Holmgren

Laboratory of

Neurogenetics, Born

Bunge Foundation,

Department of

Biochemistry,

University of

Antwerp, Belgium

E Nelis

C Van Broeckhoven

Department of

Paediatrics, Östra

Hospital, Gothenburg,

Sweden

B Westerberg

Correspondence to

Dr Holmberg, Department

of Internal Medicine

Härnösand Hospital, S-871

29 Härnösand, Sweden.

Received 7 October 1993

Revised version accepted for

publication 23 December

1993

Bengt H Holmberg, Gösta Holmgren, Eva Nelis, Christine Van Broeckhoven, Barbro Westerberg

\begin{abstract}
Sixty-seven patients in 29 families with the diagnosis of Charcot-Marie-Tooth disease or hereditary motor and sensory neuropathy in northern Sweden were examined by pedigree and DNA analysis for the CMT1a duplication within chromosome $17 \mathrm{p} 11.2$. There were 39 patients in nine families with Charcot-MarieTooth type 1 and autosomal dominant inheritance and in all these cases the duplication was seen. In six patients in three families with Charcot-MarieTooth type 1 the pedigrees strongly suggested autosomal recessive inheritance. In two patients DNA analysis was not informative but in the others no duplication was shown. There were also 11 "sporadic" patients and one pair of sibs classified as Charcot-Marie-Tooth type 1 , but there was no duplication shown although in four patients DNA analysis was not informative. In nine patients with Charcot-Marie-Tooth type 2 from five families and in 13 unaffected relatives of Charcot-Marie-Tooth patients the CMT1a duplication was not found.
\end{abstract}

( $\mathcal{F}$ Med Genet 1994;31:435-441)

Charcot-Marie-Tooth disease (CMT) or peroneal muscular atrophy or hereditary motor and sensory neuropathies (HMSN) is a genetically heterogeneous group of disorders characterised by slowly progressive motor and sensory neuropathy with foot and sometimes hand deformities and onset usually in childhood.

Current classification is based on the classification by Dyck and Lambert using clinical, genetic, electrophysiological, and pathological criteria. ${ }^{1}$ HMSN types I and II (CMT1 and 2), although clinically difficult to separate, were divided into the hypertrophic de- and remyelinating form with severely reduced nerve conduction velocities (HMSN I) and the axonal, neuronal form with normal or moderately reduced nerve conduction velocities (HMSN II). Both HMSN I and II were autosomal dominantly inherited. HMSN type III was described as a hypertrophic neuropathy with autosomal recessive inheritance and corresponded to Dejerine-Sottas disease. A motor form of CMT without any sensory impairment can also be distinguished, known as hereditary distal spinal muscular atrophy.
The finding that CMT patients could be roughly divided into two groups by nerve conduction velocity (NCV) was confirmed, and an approximate dividing value regarding nerve conduction velocity in the motor median nerve in a large sample was $38 \mathrm{~m} / \mathrm{sec}$ with some overlap. ${ }^{3}$ However, there are other studies suggesting a division into three types. ${ }^{45}$ For a firm diagnosis of CMT type 1 cases in autosomal dominant families to be used for linkage analysis, median nerve conduction velocity $\leqslant 30 \mathrm{~m} / \mathrm{sec}$ has been required. ${ }^{6}$

HMSN I is the most prevalent of all inherited neuromuscular disorders. ${ }^{7}$ In the two northernmost provinces of Sweden the prevalence of all types of CMT was estimated to be $20 \cdot 1$ per 100000 (in total 104 cases) and for CMT type 1 the prevalence rate was 16.2 per 100000 . $^{8}$

Genetic studies have indicated heterogeneity within HMSN I with a few families classified as HMSN IB (CMT1b) showing linkage to the Duffy blood group locus on chromosome 1 , but the majority of families, classified as HMSN IA (CMT1a), showing linkage to markers on chromosome $17 .{ }^{910}$ Recently a large duplication of DNA in the proximal short arm of chromosome 17 was shown in cases of CMTla and a candidate gene for CMT1a, peripheral myelin gene PMP-22, was identified mapping in the middle of the duplication. ${ }^{11-18}$

CMT is usually autosomal dominantly inherited. In most studies sporadic cases are found but with thorough clinical and electrophysiological examination of family members these cases often turn out to be hereditary..$^{19}$ There have been a few cases reported classified as HMSN I and HMSN II of probable autosomal recessive inheritance and, as for the recessive type I cases, a tendency towards being clinically more severely affected was observed. ${ }^{20}$ However, it was recently found that in nine out of 10 sporadic cases of HMSN I the duplication in chromosome 17 was present as a de novo mutation. ${ }^{21}$ Furthermore an $\mathrm{X}$ linked dominant form of CMT has been reported and also an $\mathrm{X}$ linked recessive form where linkage results indicated at least two genetic loci. ${ }^{22-24}$ In northern Sweden quite a high proportion of sporadic CMT cases was found. ${ }^{8}$

The aim of this study was to examine a series of CMT families and sporadic cases in northern Sweden with pedigree analysis and to estimate the frequency of the CMT la duplication within chromosome $17 \mathrm{p} 11.2$. 


\section{Material}

A total of 67 patients from 29 families in northern Sweden with the diagnosis of CMT were examined using family history and pedigree analysis and DNA analysis for CMT1a duplication within $17 \mathrm{p} 11.2$. The pedigrees are shown in figs 1 to 4 . Thirteen unaffected relatives were also examined by DNA analysis for the duplication. The diagnosis of CMT was established in patients with a progressive, unremitting, predominantly motor neuropathy with a typical distal localisation. Other causes of peripheral neuropathy were excluded by history and medical records. Patients with peripheral neuropathy and additional neurological signs, such as extensor plantar response, proximal muscle involvement, or cerebellar ataxia, were excluded. Patients were classified as CMT type 1 or 2 on the basis of nerve conduction velocity (NCV) in the motor median nerve with a separating value of $38 \mathrm{~m} /$ sec. One patient in an autosomal dominant CMT1 family (pedigree 2) had NCV $39 \mathrm{~m} / \mathrm{sec}$ in the motor median nerve and was classified as having CMT1. In a pair of equally disabled sibs without a family history, the brother had NCV $29 \mathrm{~m} / \mathrm{sec}$ and his sister $42 \mathrm{~m} / \mathrm{sec}$ (sensory $\mathrm{NCV}$ in the median nerve was 35 and $39 \mathrm{~m} / \mathrm{sec}$ respectively) and, although difficult to classify, they were eventually both classified as having CMT1 (pedigree 5). In a few patients NCV was not obtainable and in these cases previous NCV recordings were used for classification. Needle electromyography (EMG) was performed in most of the autosomal dominant CMT1 cases, in all CMT2 cases, and in all sporadic cases. For the diagnosis of CMT2,
NCV greater than $38 \mathrm{~m} / \mathrm{sec}$, electromyography showing denervation signs, and a typical clinical picture with onset in childhood or adolescence or an evident family history were required for inclusion.

Paternity was not tested in the sporadic CMT cases.

\section{Methods}

DNA PROBES

The DNA probes used recognise only single copy fragments and were pVAW409R3a (D17S122), pEW401HE (D17S61), pVAW412R3HEb (D17S125), and pVAW412R3HEc (D17S125). The polymorphic $M s p$ I bands with probe pVAW409R3a (D17S122) were $2 \cdot 8,2 \cdot 7$, and $1.9 \mathrm{~kb}$, and with probe pEW401HE (D17S61) 5.5 and $4.4 \mathrm{~kb}$. Probe 412 recognises two polymorphisms: pVAW412R3HEb (D17S125) with 10.5 and 5.4 and pVAW412R3HEc (D17S125) with 2.6 and $1.9 \mathrm{~kb} .{ }^{1213}$ The inserts were labelled with $1 \mathrm{mCi} / \mathrm{ml}^{32} \mathrm{P}$-dATP or ${ }^{32} \mathrm{P}$ dCTP (Amersham, $3000 \mathrm{Ci} / \mathrm{mM}$ ) or both by oligonucleotide labelling. Fifty one samples were analysed in Antwerp with all four probes, 42 samples in Umeå with probe 409 , and 12 samples in both Antwerp with all probes and Umeå with probe 409 (tables 1-3).

DNA ANALYSIS

DNA was extracted from frozen whole blood using phenol-chloroform extraction, digested, hybridised, and separated with electrophoresis according to standard procedures. ${ }^{25}$
II III

IV

V

VI

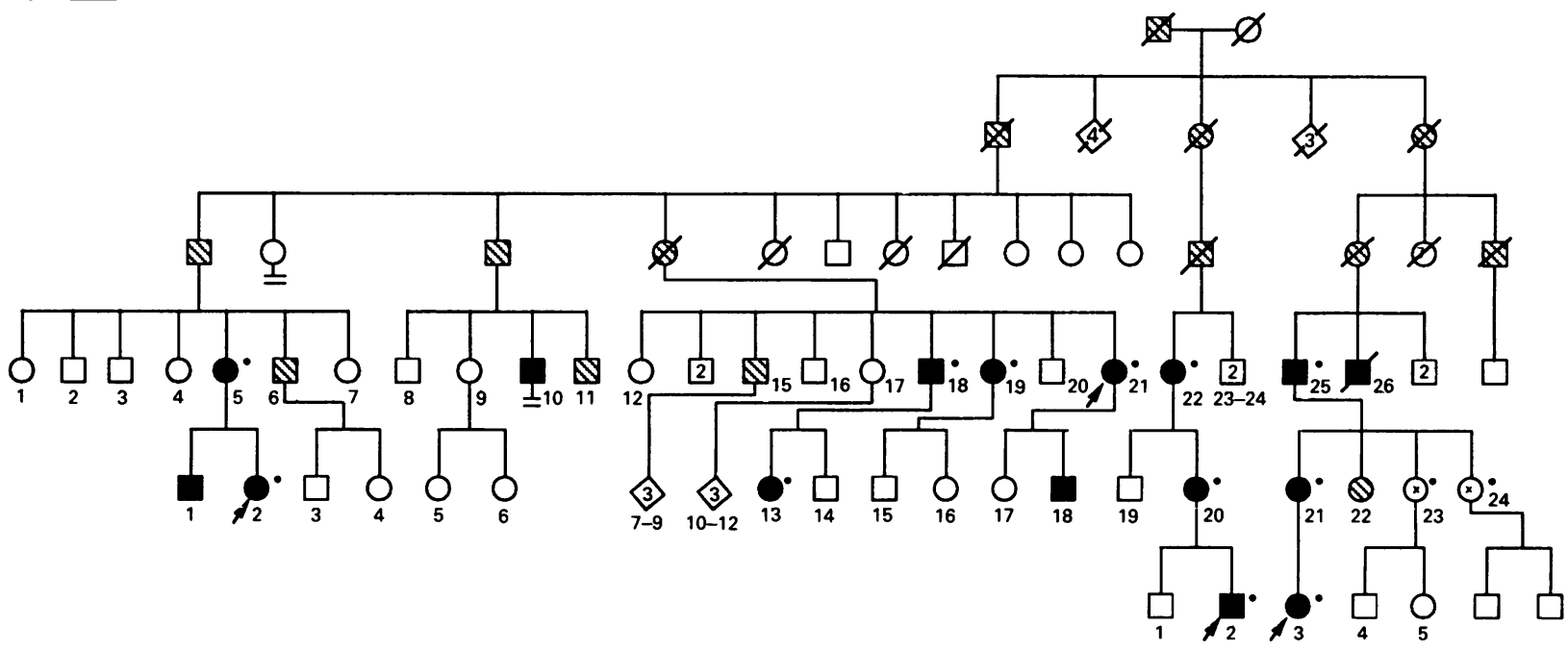

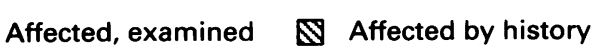

DNA analysed
Proband $\varnothing$ Dead $\odot$ Examined, not affected

Figure 1 Pedigree of a family with Charcot-Marie-Tooth disease type 1 (HMSN I) and autosomal dominant inheritance. 


\section{Pedigree 1}

11

IV

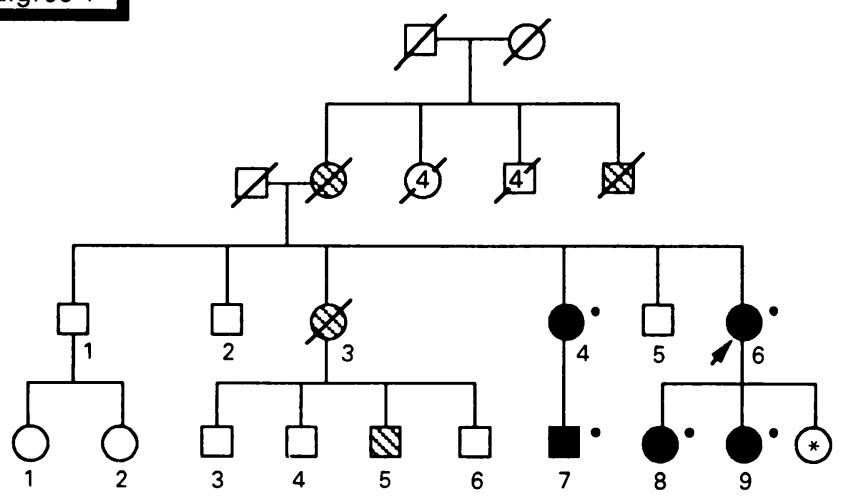

\section{Pedigree 6}

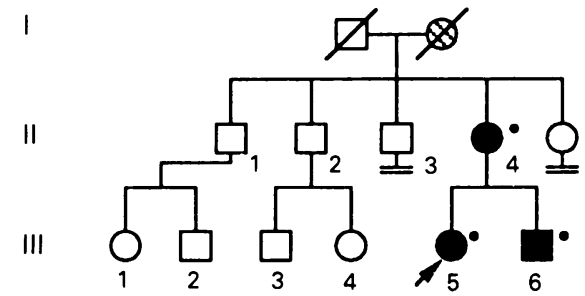

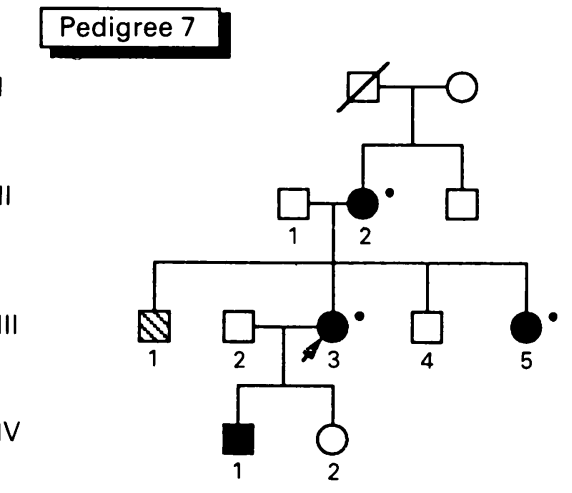

Pedigree 12
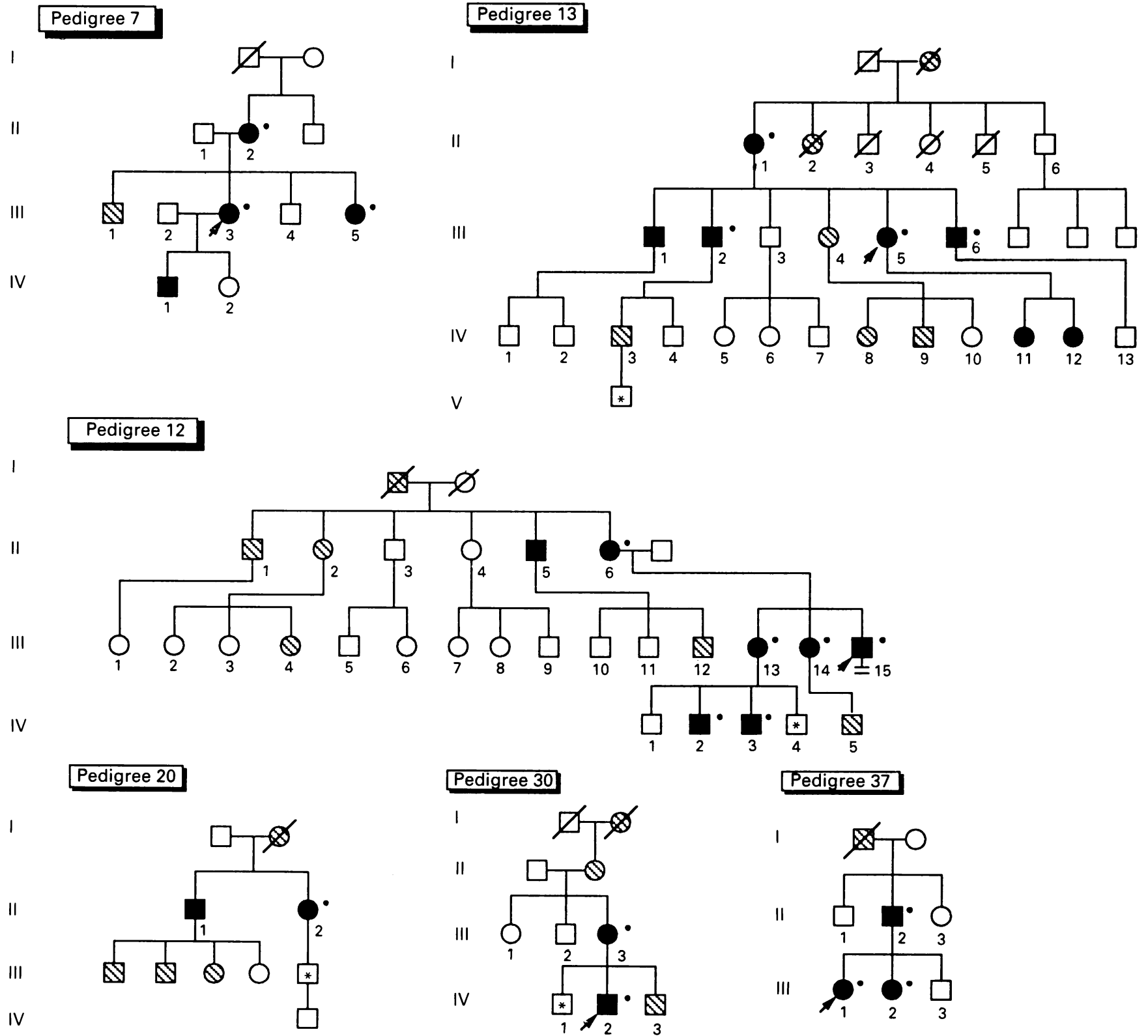

田

Results

There were 39 cases of CMT 1 in nine families with presumed autosomal dominant inheritance in pedigrees $1,2,6,7,12,13,20,30$, and 37 (table 1 ). Mean age at examination was $36 \cdot 4$ years (8-73 years) and mean NCV, when obtainable in this study, was $23.9 \mathrm{~m} / \mathrm{sec}$ (16-39 $\mathrm{m} / \mathrm{sec}$ ). In all 39 patients the CMT1a duplication in chromosome 17p11.2 could be shown (table 1).

In three CMT1 families (pedigrees 4, 9, and 31 ) with six affected cases, the pedigree ana- 
Pedigree 4

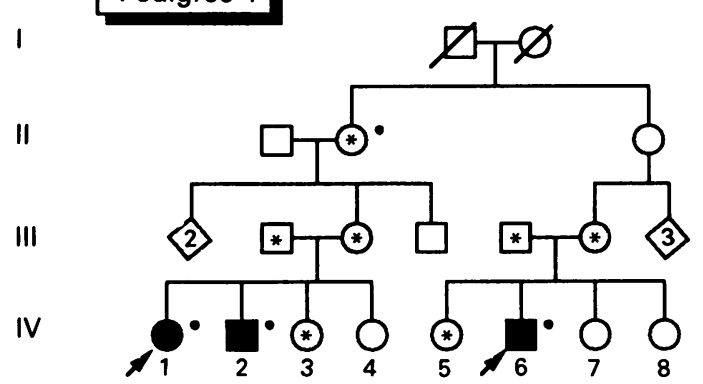

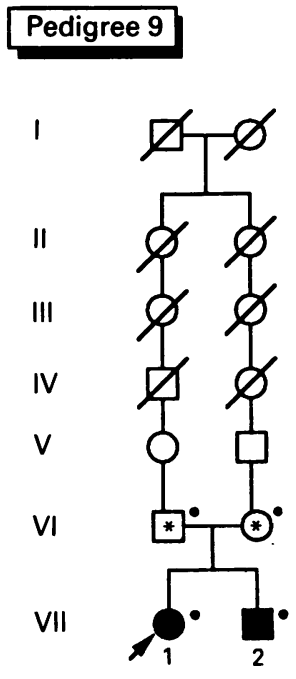

\section{Pedigree 31}

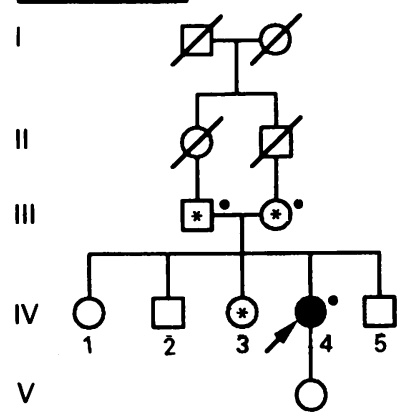

$\|$

Pedigree 19

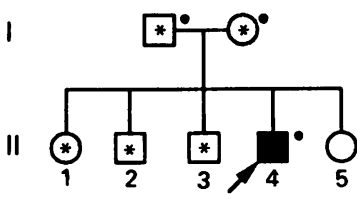

Pedigree 35

Pedigree 36
Pedigree 18

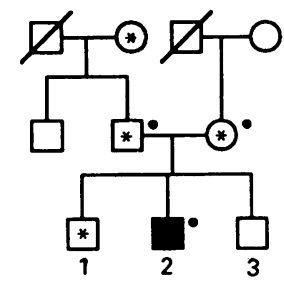

Pedigree 45

।

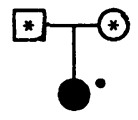

*ــ

Pedigree 22

1

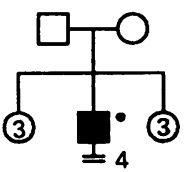

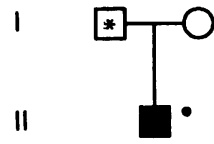

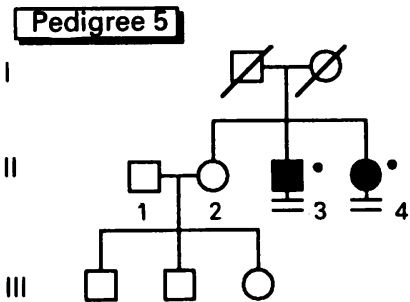

Pedigree 24

Pedigree 25

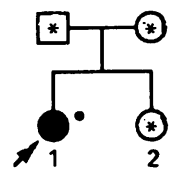

Pedigree 14

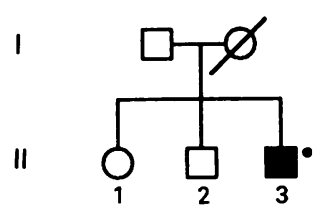

III

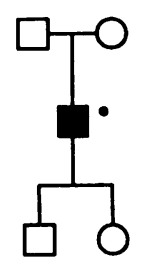

Figure 3 Three Charcot-Marie-Tooth type 1 families where pedigrees indicate autosomal recessive inheritance and pedigrees from 12 sporadic cases.

lysis indicated autosomal recessive inheritance with consanguinity in families 9 and 31 but not in family 4 . In these families, four affected patients did not show the CMT1a duplication but in two patients DNA analysis was not informative (table 2). Mean age at examination was $17 \cdot 2$ years $(8-32$ years) and mean NCV was $27 \cdot 0 \mathrm{~m} / \mathrm{sec}(21-36 \mathrm{~m} / \mathrm{sec})$.
There were also six "sporadic" CMT1 cases (pedigrees 18, 19, 35, 36, 44, and 45) with no family history of neurological disease and where both parents were examined clinically and electrophysiologically and found not to be affected. Mean NVC was $25.3 \mathrm{~m} / \mathrm{sec}(21-32 \mathrm{~m} /$ $\mathrm{sec}$ ) in the motor median nerve. In one case the DNA analysis was not informative but the 


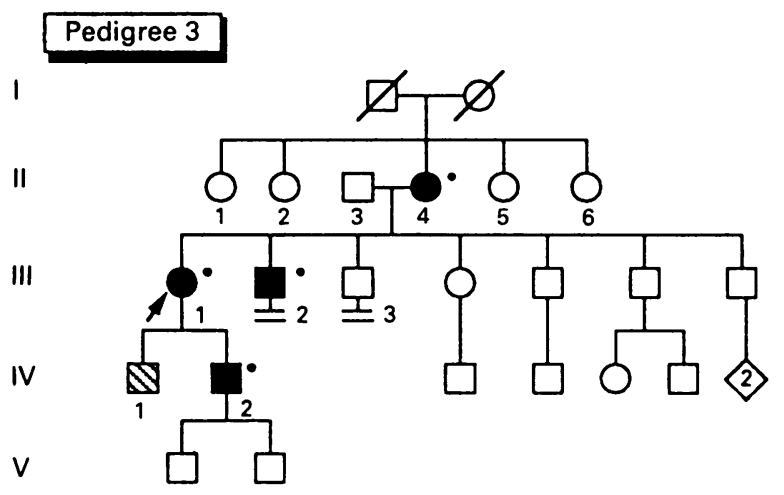

\section{Pedigree 8}

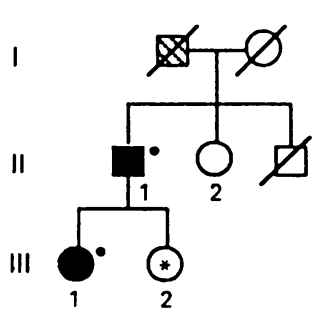

Pedigree 16

1

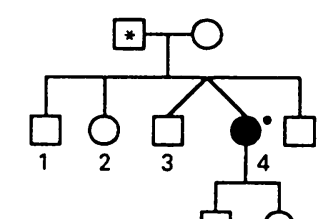

Pedigree 17

II

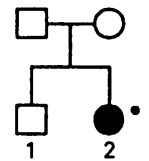

Pedigree 23

I

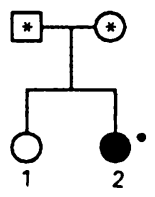

Figure 4 Pedigrees from patients with Charcot-Marie-Tooth disease type 2 (HMSN II).

other patients did not show the CMT1a duplication (table 2).

A further five CMT type 1 "sporadic" cases (pedigrees 14, 21, 22, 24, and 25) and one brother and sister pair (pedigree 5) had no previous family history of neurological disease,

Table 1 Charcot-Marie-Tooth type 1 families with autosomal dominant inheritance. $N C V=N C V$ in the motor median nerve $(\mathrm{m} / \mathrm{sec})$. U409 was analysed in Umea, A409 and the other probes were analysed in Antwerp

\begin{tabular}{|c|c|c|c|c|c|c|c|c|}
\hline Pedigree & & Age & $\mathrm{NCV}(\mathrm{m} / \mathrm{sec})$ & $A 409$ & $U 409$ & $412 b$ & $412 c$ & 401 \\
\hline $\begin{array}{l}1 \\
1\end{array}$ & $\begin{array}{l}\text { III.4 } \\
\text { IV.7 }\end{array}$ & $\begin{array}{l}62 \\
37\end{array}$ & $\begin{array}{l}32 \\
29\end{array}$ & $\begin{array}{l}112 \\
122\end{array}$ & & 122 & 112 & $\mathrm{H}$ \\
\hline i & III.6 & 52 & 23 & 112 & 122 & 122 & 112 & $\mathrm{H}$ \\
\hline 1 & IV. 8 & 20 & 20 & 122 & & 122 & 112 & $\mathrm{H}$ \\
\hline 1 & IV.9 & 32 & 37 & 122 & & 122 & 112 & $\mathrm{H}$ \\
\hline 2 & VI.3 & 20 & 21 & & 122 & & & \\
\hline 2 & V.21 & 42 & 23 & 112 & 112 & 122 & 112 & $\mathrm{H}$ \\
\hline 2 & IV.22 & 56 & 21 & 112 & & 122 & 112 & $\mathrm{H}$ \\
\hline 2 & V. 20 & 32 & 21 & 112 & & 112 & 122 & $\mathbf{H}$ \\
\hline 2 & VI.2 & 8 & & 122 & & 122 & 112 & $\mathrm{H}$ \\
\hline 2 & V.2 & 23 & $7^{*}$ & 112 & & & & $\mathbf{H}$ \\
\hline 2 & IV.5 & 51 & 25 & 122 & & 122 & 112 & $\mathrm{H}$ \\
\hline 2 & IV.18 & 44 & 20 & 122 & 122 & 122 & 112 & $\mathrm{H}$ \\
\hline 2 & V.13 & 14 & 18 & & 122 & & & \\
\hline 2 & IV.21 & 34 & 25 & & 122 & & & \\
\hline 2 & IV. 19 & 42 & 19 & & 122 & & & \\
\hline 2 & IV. 25 & 65 & & & 112 & & & \\
\hline 6 & III.5 & 30 & 23 & H & & $\mathbf{H}$ & $\mathrm{H}$ & 122 \\
\hline 6 & II .4 & 66 & 22 & 223 & & $\mathrm{H}$ & $\mathrm{H}$ & 122 \\
\hline 6 & III.6 & 22 & 18 & $\mathrm{H}$ & & $\mathrm{H}$ & $\mathbf{H}$ & 122 \\
\hline 7 & II. 2 & 57 & 23 & 112 & & $\mathrm{H}$ & $\mathrm{H}$ & 122 \\
\hline 7 & III.5 & 21 & 20 & 112 & & $\mathrm{H}$ & $\mathrm{H}$ & 112 \\
\hline 7 & III. 3 & 28 & 28 & 112 & & $\mathrm{H}$ & $\mathrm{H}$ & 122 \\
\hline 12 & II.6 & 61 & 19 & 122 & & 122 & 112 & $\mathbf{H}$ \\
\hline 12 & III.15 & 27 & 23 & 122 & & 122 & 112 & $\mathbf{H}$ \\
\hline 12 & III.14 & 37 & 22 & $\mathrm{H}$ & $\mathrm{H}$ & 122 & 122 & $\mathrm{H}$ \\
\hline 12 & III.13 & 40 & 24 & 122 & & 122 & 122 & $\mathrm{H}$ \\
\hline 12 & IV. 2 & 17 & 18 & $\mathrm{H}$ & & 112 & 122 & $\mathbf{H}$ \\
\hline 12 & IV.3 & 14 & 39 & $\mathrm{H}$ & & 122 & 112 & $\mathrm{H}$ \\
\hline 13 & II.1 & 73 & 22 & 112 & 122 & $\mathrm{H}$ & $\mathbf{H}$ & $\mathrm{H}$ \\
\hline 13 & IIII.5 & 44 & 28 & 122 & & $\mathrm{H}$ & $\mathbf{H}$ & $\mathbf{H}$ \\
\hline 13 & III. 2 & 51 & 24 & 122 & 122 & $\mathrm{H}$ & $\mathrm{H}$ & $\mathbf{H}$ \\
\hline 13 & III. 6 & 41 & 27 & 122 & 122 & $\mathbf{H}$ & $\mathbf{H}$ & $\mathrm{H}$ \\
\hline 20 & II. 2 & 44 & 33 & 122 & 122 & & & $\mathrm{H}$ \\
\hline 30 & III. 3 & 31 & 30 & 112 & & 122 & 112 & $\mathrm{H}$ \\
\hline 30 & IV. 2 & 10 & 30 & 112 & & 122 & 112 & $\mathbf{H}$ \\
\hline 37 & II. 2 & 47 & 16 & 112 & 112 & & $?$ & 122 \\
\hline 37 & III.1 & 14 & 21 & 112 & 112 & $\mathrm{H}$ & $\mathrm{H}$ & $\mathrm{H}$ \\
\hline 37 & III. 2 & 12 & 17 & 112 & 112 & $\mathrm{H}$ & $\mathrm{H}$ & $\mathbf{H}$ \\
\hline
\end{tabular}

* Not measured in this study; classification based on previous recording. $\mathrm{H}=$ homozygote. but relatives were not available for examination. In one patient the analysis was not informative and in the other four no CMT1a duplication was shown (table 2).

Nine CMT type 2 patients were also analysed for the CMT1a duplication. There were six cases in families 3 and 8 with presumed autosomal dominant inheritance and three "sporadic" cases in pedigrees 16, 17, and 23 . In three patients the DNA analysis was not informative and in the other cases there was no duplication (table 3). The DNA of 13 clinically and electrophysiologically unaffected relatives was also analysed and no duplication was detected (table 3).

\section{Discussion}

In all 39 examined cases of CMT1 in nine autosomal dominant families the CMT1a duplication in chromosome $17 \mathrm{p} 11.2$ was shown and these patients could accordingly be classified as CMT1a (HMSN IA).

In northern Sweden there seems to be a rather large proportion of isolated or sporadic CMT cases. ${ }^{8}$ There are published reports on autosomal recessive CMT1 cases but this form has been considered rare. ${ }^{20}$ When recently, in a series of 10 sporadic cases of CMT1, the DNA was analysed for the CMT1a duplication, it was shown that nine out of 10 cases were duplicated following a de novo mutation. ${ }^{21}$ However, in the present material from northern Sweden none of the sporadic CMT1 cases or the CMT1 sibs with unaffected parents showed the CMT1a duplication, and for six of these patients the pedigrees strongly suggested autosomal recessive inheritance (pedigrees 4 9, and 31). In six of the patients the DNA analysis was not informative.

Although paternity was not tested, the re- 
Table 2 Charcot-Marie-Tooth patients classified as autosomal recessive (rec?) or sporadic (spor) cases. NCV $=N C V$ in the motor median nerve $(\mathrm{m} / \mathrm{sec})$. U409 was analysed in Umea, A409 and the other probes in Antwerp

\begin{tabular}{|c|c|c|c|c|c|c|c|c|c|c|}
\hline \multicolumn{2}{|c|}{ Pedigree } & \multirow{2}{*}{$\begin{array}{l}\text { Sex } \\
\mathrm{F}\end{array}$} & \multirow{2}{*}{$\frac{\text { Age }}{11}$} & $\mathrm{NCV}(\mathrm{m} / \mathrm{sec})$ & \multirow{2}{*}{$\begin{array}{l}\text { CMT type } \\
\text { CMT } 1 \text { rec? }\end{array}$} & \multirow{3}{*}{$\begin{array}{l}A 409 \\
\mathrm{H} \\
\mathrm{H}\end{array}$} & $U 409$ & \multirow{2}{*}{$\frac{412 b}{\mathrm{H}}$} & \multirow{2}{*}{$\begin{array}{l}412 c \\
\mathrm{H}\end{array}$} & \multirow{2}{*}{$\frac{401}{12}$} \\
\hline 9 & igree & & & 21 & & & & & & \\
\hline \multirow{3}{*}{$\begin{array}{l}9 \\
4 \\
4 \\
4\end{array}$} & VII.2 & $\begin{array}{l}M \\
F\end{array}$ & $\begin{array}{r}8 \\
20\end{array}$ & $\begin{array}{l}21 \\
28\end{array}$ & CMT 1 rec? & & \multirow{2}{*}{12} & & & 12 \\
\hline & IV.2 & M & 17 & 36 & CMT 1 rec? & $\mathrm{H}$ & & & $\mathrm{H}$ & $\mathrm{H}$ \\
\hline & IV.6 & $\mathbf{M}$ & 15 & 29 & CMT 1 rec? & & 12 & & & \\
\hline \multirow{4}{*}{$\begin{array}{l}31 \\
18 \\
19 \\
35\end{array}$} & IV.4 & $\mathrm{F}$ & 32 & $23^{*}$ & CMT 1 rec? & $\mathrm{H}$ & 12 & $\mathrm{H}$ & $\mathrm{H}$ & $\mathrm{H}$ \\
\hline & II. 2 & $\mathbf{M}$ & 12 & 29 & CMT 1 spor & $\mathrm{H}$ & & 12 & 12 & $\mathrm{H}$ \\
\hline & II.4 & $M$ & 15 & 32 & CMT 1 spor & & 22 & & & \\
\hline & & $\mathbf{M}$ & 21 & 28 & CMT 1 spor & & 12 & & & \\
\hline 36 & & $\mathrm{~F}$ & 17 & 23 & CMT 1 spor & & 12 & & & \\
\hline $\begin{array}{l}3 \\
4 \\
4\end{array}$ & & $\mathrm{~F}$ & 23 & 22 & CMT 1 spor & & 12 & & & \\
\hline 4 & & M & 24 & 21 & CMT 1 spor & & 12 & & & \\
\hline \multirow{2}{*}{14} & II. 3 & $M$ & 40 & 23 & CMT 1 spor & & 12 & & & \\
\hline & & $\mathbf{M}$ & 19 & 28 & CMT 1 spor & & 12 & & & \\
\hline $\begin{array}{l}2 \\
2 \\
2\end{array}$ & & M & 38 & $21^{*}$ & CMT 1 spor & 12 & 12 & $\mathrm{H}$ & $\mathrm{H}$ & $\mathrm{H}$ \\
\hline \multirow{2}{*}{24} & II.4 & $\mathbf{M}$ & 42 & 22 & CMT 1 spor & & 12 & $\mathbf{H}$ & $\mathrm{H}$ & \\
\hline & II.1 & $\mathrm{F}$ & 22 & 23 & CMT 1 spor & & 12 & & & \\
\hline \multirow{2}{*}{$\begin{array}{l}5 \\
5\end{array}$} & II. 3 & $\mathbf{M}$ & 45 & 29 & CMT 1 & & 12 & & & \\
\hline & II.4 & $\mathbf{F}$ & 44 & 42 & CMT 1 & & 11 & & & \\
\hline
\end{tabular}

* Not measured in this study; classification based on previous recording. $\mathrm{H}=$ homozygote.
CMT1 family and the CMT1a duplication in $17 \mathrm{p} 11.2$ was found. No other patient in this sample had an age of onset within the first two years of life and in no case where NCV was measured was it $12 \mathrm{~m} / \mathrm{sec}$ or less. We suggest that most of the sporadic CMT1 patients and sibships without the CMT1a duplication in this sample from northern Sweden are autosomal recessive CMT1 cases.

The finding of a duplication in chromosome 17 p11.2 in CMT1a has considerably facilitated the examination of patients with peripheral neuropathy. When the duplication is found the diagnosis of CMTla is established and reliable genetic counselling and prenatal diagnosis can be offered. However, sometimes the CMT1a duplication may be difficult to show using Southern blot hybridisation of $M s p$ I digested DNA with the polymorphic probes 409,412 , and 401 owing to homozygosity. In these cases the use of additional probes, or of a different method such as quantitative dosage analysis, is needed to show the presence or absence of the CMT1a duplication. In this study 34 out of 39 cases in the CMT1 autosomal dominant families were informative for the CMTla duplication using only probe 409 , and when using all four probes all 39 cases were informative. dic CMT1 patients it is not possible to rule out an $\mathrm{X}$ linked mode of inheritance; however, there is no pedigree support for this in our series. It has been a matter of discussion whether proven recessive HMSN I cases (hypertrophic form of Charcot-Marie-Tooth disease) should be classified as HMSN III or HMSN I with autosomal recessive inheritance. ${ }^{2627}$ In this study there was a 24 year old woman (V.2 in pedigree 2) who at the age of 4 years already had an extremely reduced NCV $(\mathrm{NCV}<10 \mathrm{~m} / \mathrm{sec})$ and who clinically showed an early and pronounced peripheral neuropathy. Nerve biopsy showed "a picture compatible with HMSN III". In adolescence the clinical features of Turner's syndrome appeared and she was found to have the karyotype $46, \mathrm{X}$ (iso $\mathrm{Xq}$ ). However, she was then shown to belong to an autosomal dominant

Table 3 Charcot-Marie-Tooth type 2 cases and unaffected relatives of CMT patients, all types. NCV $=N C V$ in the motor median nerve $(\mathrm{m} / \mathrm{sec})$. U409 was analysed in Umea, A409 and the other probes in Antwerp. CMT2 AD=CMT type 2 autosomal dominant inheritance. CMT2 spor = sporadic cases of CMT2.

\begin{tabular}{|c|c|c|c|c|c|c|c|c|c|}
\hline \multicolumn{2}{|c|}{ Pedigree } & \multirow{2}{*}{$\frac{\text { Age }}{34}$} & $\mathrm{NCV}(\mathrm{m} / \mathrm{sec})$ & \multirow{2}{*}{$\begin{array}{l}A 409 \\
23\end{array}$} & $U 409$ & $412 b$ & $412 c$ & \multirow{2}{*}{$\frac{401}{12}$} & \multirow{2}{*}{$\begin{array}{l}\text { Diagnosis } \\
\text { CMT2 AD }\end{array}$} \\
\hline 3 & IV.2 & & 59 & & & 12 & 12 & & \\
\hline 3 & III.1 & 56 & 49 & 12 & & 12 & $\mathrm{H}$ & 12 & CMT2 AD \\
\hline 3 & III. 2 & 54 & 48 & $\mathbf{H}$ & & $\mathbf{H}$ & $\mathrm{H}$ & $\mathrm{H}$ & CMT2 AD \\
\hline 3 & II.4 & 75 & 52 & $\mathbf{H}$ & & & & & CMT2 AD \\
\hline 8 & II.1 & 65 & 48 & 12 & & $\mathbf{H}$ & $\mathrm{H}$ & $\mathbf{H}$ & $\mathrm{CMT} 2 \mathrm{AD}$ \\
\hline 8 & III.1 & 41 & 48 & $\mathbf{H}$ & & & & $\mathrm{H}$ & $\mathrm{CMT} 2 \mathrm{AD}$ \\
\hline 17 & II. 2 & 24 & 45 & 12 & & $\mathrm{H}$ & 12 & 12 & CMT2 spor \\
\hline 16 & II.4 & 31 & 41 & 12 & & 22 & 12 & 12 & CMT2 spor \\
\hline 23 & II. 2 & 23 & 48 & & 13 & & & & CMT2 spor \\
\hline 2 & V. 23 & 29 & 54 & $\mathbf{H}$ & & 12 & 12 & $\mathrm{H}$ & Not affected \\
\hline 2 & V. 24 & 26 & 62 & $\mathrm{H}$ & & 12 & 12 & $\mathrm{H}$ & Not affected \\
\hline 4 & II.2 & 60 & 48 & $\mathrm{H}$ & & & & $\mathbf{H}$ & Not affected \\
\hline 35 & I. 1 & 47 & 62 & & 22 & & & & Not affected \\
\hline 35 & I. 2 & 45 & 58 & & 12 & & & & Not affected \\
\hline 18 & II.1 & 52 & 55 & & 12 & & & & Not affected \\
\hline 18 & II. 2 & 48 & 57 & & 12 & & & & Not affected \\
\hline 31 & III. 1 & 70 & 52 & & 12 & & & & Not affected \\
\hline 31 & III. 2 & 65 & 56 & & 12 & & & & Not affected \\
\hline 19 & I. 1 & 50 & 61 & & 12 & & & & Not affected \\
\hline 19 & I. 2 & 47 & 55 & & 22 & & & & Not affected \\
\hline 9 & I. 1 & 37 & 57 & & 11 & & & & Not affected \\
\hline 9 & I. 2 & 37 & 56 & & 11 & & & & Not affected \\
\hline
\end{tabular}

$\mathrm{H}=$ homozygote. This work was supported by grants from "Anslag till forskning
för Hälso- och sjukvărden i Norra Regionen", Sweden (BH), the Kempe Foundation, Örnsköldsvik, Sweden (BH), the Swedish Medical Research Foundation (GH), Neurologiskt Handikappades Riksförbund, Sweden (BH), the Flemish Biotechnology Programme, Belgium, the Institute of Scientific Research in Industry and Agriculture, Belgium (EN), the National Fund for Scientific Research, Belgium (CVB) and "Förstamajblommans Riksförbund", Sweden (BW). The skilful work of Ann-
acknowledged.

1 Dyck PJ. Inherited neuronal degeneration and atrophy affecting peripheral motor, sensory and autonomic neurons. In: Dyck PJ, Thomas PK, Lambert EH, Bunge R eds. Peripheral neuropathy. 2nd ed. Philadelphia

2 Thomas PK, Calne DB. Motor nerve conduction velocity in peroneal muscular atrophy: evidence for genetic heterogeneity. I Neurol Neurosurg Psychiatry 1974;37:68-75.

3 Harding AE, Thomas PK. The clinical features of hereditary motor and sensory neuropathy types I and II. Brain 1980;103:259-80

4 Brust J, Lovelace R, Devi S. Clinical and electrodiagnostic feature of Charcot-Marie-Tooth syndrome. Acta Neurol Scand Suppl 1978;58:1-42.

5 Davis CJF, Bradley WG, Madrid R. The peroneal muscular atrophy syndrome. Clinical, genetic, electrophysiological and nerve biopsy studies. I. Clinical, genetic and electrophysiological findings and classification. $\mathcal{f}$ Gene Hum 1978;26:311-49.

6 De Visser M. Diagnostic criteria for autosomal dominan hereditary motor and sensory neuropathy type 1a. Neuromusc Dis 1993;3:77-9.

7 Emery AEH. Population frequencies of inherited neuromuscular diseases - a world survey. Neuromusc Dis 1991;1:19-29.

8 Holmberg BH. Charcot-Marie-Tooth disease in northern Sweden - an epidemiological and clinical study. Acta Neurol Scand 1993;87:416-22.

9 Bird TD, Ott J, Giblett ER. Evidence for linkage of Charcot-Marie-Tooth neuropathy to the Duffy locus on chromosome 1. Am f Hum Genet 1982;34:388-94.

10 Vance J, Barker D, Yamaoka L, et al. Localization of Charcot-Marie-Tooth disease type 1a (CMT1A) to chromosome 17p11.2. Genomics 1991;9:623-8.

11 Lupski J, Montes de Oca-Luna R, Slangenhaupt S, et al. DNA duplication associated with Charcot-Marie-Tooth disease type 1A. Cell 1991;66:219-32.

12 Raeymaekers P, Timmerman V, Nelis E, et al. Duplication in chromosome 17p11.2 in Charcot-Marie-Tooth neuroin chromosome 17p11.2 in Charcot-Marie-Tooth neure

13 Raeymaekers P, Timmerman V, Nelis E, et al. Estimation of the size of the chromosome $17 \mathrm{p} 11.2$ duplication in of the size of the chromosome $17 \mathrm{p} 11.2$ duplication in
Charcot-Marie-Tooth neuropathy type la (CMT1a). f Med Genet 1992;29:5-11.

14 Suter U, Welcher A, Özcelik T, et al. Trembler mouse carries a point mutation in a myelin gene. Nature carries a point 
15 Patel P, Roa B, Welcher A, et al. The gene for the peripheral myelin protein PMP-22 is a candidate for Charcot-MarieTooth disease type 1A. Nature Genet 1992;1:159-63.

16 Valentijn L, Bolhuis P, Zorn I, et al. The peripheral myelin gene PMP-22 GAS-3 is duplicated in Charcot-MarieTooth disease type 1A. Nature Genet 1992;1:166-70.

17 Timmerman V, Nelis E, Van Hul W, et al. The peripheral myelin protein gene PMP-22 is contained within the Charcot-Marie-Tooth disease type 1A duplication. Charcot-Marie-Tooth disease

18 Matsunami N, Smith B, Ballard L, et al. Peripheral myelin protein-22 gene maps in the duplication in chromosome 17 p11.2 associated with Charcot-Marie-Tooth 1A. $\mathrm{Na}$ ture Genet 1992;1:176-9.

19 Dyck PJ, Karnes JL, Windebank AJ, Sparks M, Clarkestevens J, O'Brien PC. Minimal pathologic expression of a mutant gene for hereditary motor and sensory neuropathy. Mayo Clin Proc 1983;58:419-25.

20 Harding AE, Thomas PK. Autosomal recessive forms of hereditary motor and sensory neuropathy. $\mathcal{f}$ Neurol Neurosurg Psychiatry 1980;43:669-78.

21 Hoogendijk JE, Hensels GW, Gabreels-Festen AA, et al.
De-novo mutation in hereditary motor and sensory neuropathy type I. Lancet 1992;339:1081-2.

22 Iselius L, Grimby L. A family with Charcot-Marie-Tooth disease showing a probable $\mathrm{X}$-linked incompletely dominant inheritance. Hereditas 1982;97:157-8.

23 Rozear MP, Pericak-Vance MA, Fishbeck K, et al. Hereditary motor and sensory neuropathy, X-linked: a half century follow up. Neurology 1987;37:1460-5.

24 Ionasescu V, Trofatter J, Haines J, Summers A, Ionasescu $R$, Searby C. Heterogeneity in X-linked recessive Charcot-Marie-Tooth neuropathy. Am $f$ Hum 1991;48:1075-83.

25 Sambrook J, Fritsch EF, Maniatis T. Molecular cloning: a laboratory manual. 2nd ed. Cold Spring Harbor, New York: Cold Spring Harbor Laboratory Press, 1989.

26 Westerberg B. Neuropediatric aspects of hereditary peripheral neuropathy in childhood. MD thesis, University of pheral neuropathy in childho

27 Ouvrier R, McLeod J, Conchin T. The hypertrophic forms of hereditary motor and sensory neuropathy. A study of hypertrophic Charcot-Marie-Tooth disease (HMSN type I) and Dejerine-Sottas disease (HMSN type III) in I) and Dejerine-Sottas disease ( 